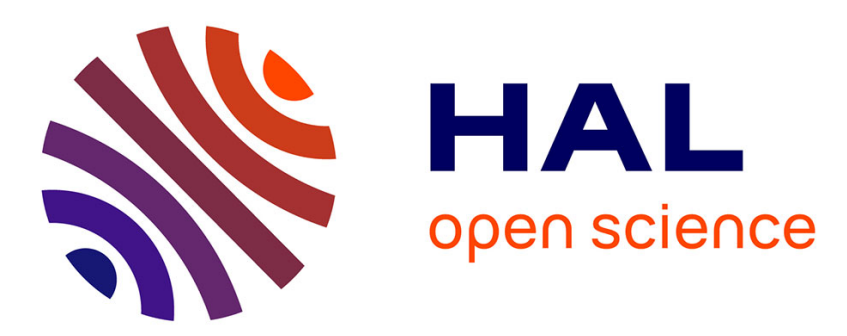

\title{
Cross-sector dialogue for sustainability: To partner or not to partner?
}

Céline Louche, Suzanne Young, Martin Fougère

\section{To cite this version:}

Céline Louche, Suzanne Young, Martin Fougère. Cross-sector dialogue for sustainability: To partner or not to partner?. Sustainability Accounting, Management and Policy Journal, inPress. hal-03231763

\section{HAL Id: hal-03231763 \\ https://hal-audencia.archives-ouvertes.fr/hal-03231763}

Submitted on 25 May 2021

HAL is a multi-disciplinary open access archive for the deposit and dissemination of scientific research documents, whether they are published or not. The documents may come from teaching and research institutions in France or abroad, or from public or private research centers.
L'archive ouverte pluridisciplinaire HAL, est destinée au dépôt et à la diffusion de documents scientifiques de niveau recherche, publiés ou non, émanant des établissements d'enseignement et de recherche français ou étrangers, des laboratoires publics ou privés. 


\section{Cross-sector dialogue for sustainability: To partner or not to partner?}

Céline Louche, Audencia Business School, Nantes, France, clouche@ audencia.com

Suzanne Young, La Trobe Business School, La Trobe University, Melbourne, Australia, S.H.Young@latrobe.edu.au

Martin Fougère, Hanken School of Economics, Finland, martin.fougere@ hanken.fi

\section{Published in:}

Sustainability Accounting, Management and Policy Journal (forthcoming). DOI (10.1108/SAMPJ-02-2021-0045) 


\title{
Cross-sector dialogue for sustainability: To partner or not to partner?
}

\begin{abstract}
Purpose - The purpose of this paper is to introduce the topic and review the contributions of the special issue papers on cross-sector dialogue for sustainability. The paper also presents avenues for further research.

Design/methodology/approach - The paper is based on a review of the current literature on cross-sector partnership and dialogue. It explores the current issues in cross-sector partnerships through a discussion of the papers accepted for the special issue, their focus, findings, and key contributions.
\end{abstract}

Findings - It highlights three main key research themes and learnings from the special issue papers: 1) a high level of 'hybridity' of collaboration forms, which involve important tensions; 2) a need to understand partnership in its context; 3) the importance of the individual level in cross-sector collaboration.

Practical implications - The authors call for attention to be paid to two forms of myopia: a tendency to view partnerships primarily from a resource-based view (without much attempt to measure societal impact) and a reluctance to be explicitly critical (despite empirical evidence of some suboptimal aspects of partnerships).

Social implications - The authors call for researchers to move away from a resource based approach to one that is situated in exploring the value derived from partnerships in the broader societal context. We suggest some avenues for further research to move the discussion beyond the partnership imperative.

Originality/value - The paper outlines the need to critically revisit the very essence of what real partnership means and whether dialogue is really taking place.

Keywords - Cross sector partnership; dialogue; sustainability; CSR 


\section{The cross-sector partnership imperative}

As we - the UN, governments, businesses, NGOs, academics and others - work towards building a more sustainable world, a transformative approach calling for more partnerships is necessary (Horan, 2019; Sachs et al., 2019). In other words: we cannot work in isolation. Cross-sector coordination and collaborations (public, private, and nonprofit) are necessary to advance sustainability and implement the Sustainable Development Goals (SDGs) (Clarke \& Crane, 2018; Murray et al., 2010; Vestergaard et al., 2020). It provides opportunities to overcome individual limitations by combining the competences, skills, and expertise of different types of actors, and thereby provides a mechanism to address some of the challenges related to regulation, participation, implementation, resources and learning (Kolk, 2014).

The partnership imperative is at the core of SDG 17. This SDG focuses on strengthening and revitalizing partnerships for sustainable development. Target 17.16 calls for "mobiliz[ing] and shar[ing] knowledge, expertise, technology and financial resources, to support the achievement of the sustainable development goals in all countries" (UN, 2019, Target 17.16), while Target 17.17 encourages and promotes "effective public, public-private and civil society partnerships" that build upon partnership experience and resourcing strategies (UN, 2019). This emphasis on partnership has stimulated an increasing interest from both research and practice (e.g. Clarke \& Crane, 2018; Seitanidi \& Crane, 2009; Seitanidi \& Crane, 2014; Van Tulder et al., 2016).

The term partnership (or cross-sector partnership, CSP) refers to forms of collaborations between actors from different sectors. Huxham and Vangen (2005) defines it as a "type of cooperative, interorganizational relationship" where people are "working across organizational boundaries towards some positive end" (p. 4). In the context of the SDG, the purpose of partnerships is to bring about sustainable changes and thereby contribute to societal betterment (Vestergaard et al., 2020). Although 'partnership' and 'collaboration' are often used interchangeably, it might be useful to distinguish them. 'Partnership' tends to be formal and situated at the institutional-level and synonymous with the structure of 'working together'. It refers to arrangements between institutional actors. 'Collaboration' can be considered as a more active form of 'working together'. It refers to the collection of knowledge, skills, values and motives applied by the actors to put into practice formal or less 
formal joint working arrangements. In other words, 'partnership' is the state of the relationship, at the organizational or group level, while 'collaboration' is an active process of partnership-in-action (Whittington, 2003).

The notion of partnership has been of particular interest in business and society literature (Vestergaard et al., 2020). It has been defined as a voluntary form of collaboration "between actors from organizations in two or more economic sectors in a forum in which they cooperatively attempt to solve a problem or issue of mutual concern that is in some way identified with a public policy agenda item" (Waddock, 1991, pp. 481-482). Clarke and Crane (2018, p. 303) present partnerships as "relatively intensive, long-term interactions between organizations from at least two different stakeholders aimed at addressing a social and/or environmental problem".

Cross-sector partnerships can encompass two parties or multi-stakeholder, public-privatecivic endeavors involving multiple parties (including business, government, NGOs, and civil society) coming together to address single or multiple issues. The inclusion of multiple stakeholders is critical for any collaboration to be regarded as legitimate (Mena \& Palazzo, 2012) even if the principle of inclusiveness may be a source of tension (Henry et al., 2020). The level of engagement of the stakeholders is an important determinant to characterize the type of relationships. Austin (2000) proposes three main types--philanthropic, transactional and integrative - where at one end of the spectrum the nature of the partnership requires low commitments and is mainly based on charitable donor-recipient relationship, while at the other end partnerships are more integrative, involving higher levels of commitment, engagement and interaction.

In general, partnerships have been presented as key instruments to address the complexity of the sustainability challenges (Murray et al., 2010). They are regarded as essential to access resources, share risk, increase efficiency and foster organizational learning (Huxham \& Vangen, 2005; Murray et al., 2010). partnerships are increasingly being adopted to address sustainability issues in the areas of education, ecological diversity, economic development or climate change (Clarke \& Ordonez-Ponce, 2017; Crane \& Seitanidi, 2014). Moreover, such relationships are seen to be beneficial in tackling the important societal issues that cannot be dealt with alone (Murray et al., 2010; Waddock, 1989). Therefore some have described partnerships as a "magic formula" (Rundall, 2000, p. 1501) to fight global problems. As Van Huijstee et al. (2007) wrote: "the complex character of sustainability problems demands the 
active involvement of all societal spheres to resolve them" (p.76). As of January $27^{\text {th }}, 2021$, the Partnerships for SDG platform contained 5,331 partnerships and voluntary initiatives for SDGs, registered by different stakeholders. ${ }^{1}$

This is not to say that partnerships should be seen in all cases as the universal panacea implied by SDG17. Glasbergen (2011, p. 6) notes that "potential partners will only collaborate structurally if each of them is convinced it stands to gain from the partnership". Certainly not all sustainability challenges can be effectively addressed through an approach that includes among its premises the possibility for all involved actors to gain from collaborative work. Many sustainability challenges are framed as 'wicked problems' and therefore no 'solution' for those can be found that does not involve some of their stakeholders being impacted negatively (see e.g. Head, 2008). This means that the actors partnering in attempting to tackle wicked problems will be those who can benefit from the proposed solutions, and that those who stand to be affected negatively will typically be excluded - or exclude themselves - from the partnerships, thereby further marginalized. Evidence for such detrimental effects of partnerships can be found in studies of multi-stakeholder initiatives (Cheyns, 2014; Fougère \& Solitander, 2020; Schouten et al., 2012), for example. Thus, depending on the sustainability challenge we are attempting to address, it is relevant to ask whether partnering is likely to be an effective approach, or whether other types of approaches to dialogue might be desirable instead.

With this introductory article, we wish to push the discussion beyond the focus on understanding the characteristics contributing to successful partnerships. After reviewing the critical factors that lead to positive outcomes, we question the nature of the partnership form and whether this form is always the most desirable avenue for sustainable development. In its critique, the introductory article also explores the link between dialogue and partnership as well as pointing to how incorporating concepts of dissent and resistance within these forms would attune business research to the political and social complexity of cross-sector interactions.

\footnotetext{
${ }^{1}$ https://sustainabledevelopment.un.org/partnerships/, Accessed on the 27/01/2021
} 


\section{What makes a successful partnership?}

Normatively speaking, partnerships are generally meant to be non-hierarchical and voluntary (Selsky \& Parker, 2005), although they may not always be so in practice. They are pluralist in form with each partner contributing their resources and strengths (Crane \& Seitanidi, 2014), whilst providing a platform for negotiating between stakeholders (Lotia \& Hardy, 2008). Partnerships typically aim to create public value that cannot otherwise be achieved by individual actors (Bryson et al., 2006). The partnership form also provides voice to new stakeholder groups who are often under-represented in more traditional business-led sustainability initiatives (Pedersen et al., 2020). Acknowledging that multi-stakeholder partnerships are comprised of multiple stakes with multiple goals and multiple forms of value creation is an important stepping-stone to developing and managing organizations working towards shared purposes (Pedersen et al., 2020). Even so, potential partners will only collaborate if each is convinced it stands to gain from the partnership (Glasbergen, 2011). Such collaborative models also face the challenge of aligning differing perceptions of time with temporal tensions that occur between different stakeholders, all of which need to be considered and managed (Pedersen et al., 2020).

According to Clarke and Fuller (2010), adopting business-type paradigms, the partnering process begins with (1) formation phase, or understanding the context, (2) identifying partner organizations and required resources, and (3) developing a collaborative strategic plan. Implementation follows where the plan is implemented cooperatively and independently by each partner, with each partner monitoring and appraising. As a result, outcomes are produced for the partners, other stakeholders, and society / the environment.

Ordonez-Ponce and Clarke (2020) in their study of structures and sustainability partnerships found that for businesses and public organizations, the most relevant contributors to outcomes were formal structures such as having a budget, a new department and infrastructure, generating new revenue, and having a sustainability position. On the other hand, for civil society organisations, informal structures were key. It was not just that structures were important but the type of structures the partners used were influential (Ordonez-Ponce and Clarke (2020).

Gray and Stites (2013) have defined three critical areas to consider for a successful partnership: selection of the right type of partnership, selection of the right type of partner, 
and careful management of the partnership process. Research uncovering the processes partnerships use has been an important stimulus to the literature over the past few decades, moving from the focus on antecedents of collaboration, partnership life formation and partner relationships (Austin \& Seitanidi, 2012; MacDonald et al., 2019). Understanding mechanisms of coordination, collaboration processes and organizational design aspects are important contributions (Albers et al., 2013; MacDonald et al., 2019). Cooperation and consultation processes involved in such partnerships can result in new ideas and creative solutions, efficiency and effectiveness improvements and shared accountability (Fadeeva, 2005). MacDonald et al. (2019) studied sustainability partnerships and collaborative decisionmaking and found that such decision-making has a positive impact on partnership capacity through sharing of information, coordination of partner interactions, and facilitation of ongoing learning. In the design of decision-making processes, internal mechanisms that coordinate and monitor collaboration are key.

McDonald and Young (2012) highlight that for partnerships key success factors are leadership, effective communication and trust. In addition, for the partnership to move towards more complex arrangements requires government and employee support, interaction and engagement, and evaluation and monitoring indicators. They also cautioned NGOs of the risks of co-option, that is, co-option of NGOs by corporations where the corporations exert their power to focus the partnership on their goals rather than a win-win outcome. Such risks can be lessened with the use of open communication, power sharing and interdependencies between the parties (McDonald and Young (2012).

Other studies have examined the performance or effectiveness of partnerships (Clarke \& Fuller, 2010; Clarke \& Macdonald, 2019; Seitanidi et al., 2010; Tulder et al., 2016) exploring the development of metrics, questioning the meaning of performance, identifying the key success factors and investigating the challenges of aligning sometimes conflicting goals. Even though there inevitably has to be some common interests, the parties may not share values or goals, interests and objectives (Murray et al., 2010). Each party is beholden to their own hierarchies and market mechanisms and stakeholders. Compared to alliances within sectors, cross sector alliances are more difficult to form and maintain due to divergent mission and purpose which can create unexpected inter-organizational conflict (Rondinelli \& London, 2003). Rondinelli and London (2003) contend that inherent distrust and lack of 
experience with the other sector(s) lead to the alliances being often unsuccessful. Developing and maintaining trust through collaboration processes is key.

\section{Critical voices about partnerships}

The previous section revealed the depth of research in and around partnerships. Those studies have provided important insights contributing to a better understanding of the success factors of effective partnerships. The spread and seductiveness of the partnership form is such, that it is difficult today to find a policy or an academic document that does not have partnership in its recommendations or even as a central element of its strategy for the delivery of the SDGs. The pressure to collaborate and join in partnerships is overwhelming. However, despite the popularity of partnerships, or perhaps because of the unanimous support for them, some critical voices have started to rise. The need to work collaboratively in the context of complex problems, uncertainties and long-term issues appears to be obvious. Yet if potential partners only collaborate if they stand to gain from partnerships (Glasbergen (2011, p. 6), those who might be affected negatively by the proposed solutions often end up further marginalized (Cheyns, 2014; Fougère \& Solitander, 2020; Schouten et al., 2012). Thus, the overwhelmingly positive view of partnerships as the best way to address complex problems could become a problematic bias.

Besides this general concern, researchers have discussed a number of pitfalls of partnerships. Clarke and Crane (2018) argue that research remains partial and fragmented and the type of transformational change expected from and achieved by partnerships is far from being clear. Beyond the challenges of forming, managing, and maintaining collaborations and partnerships (Gupta et al., 2018; Rondinelli \& London, 2003), we still know very little about the value of partnerships, that is "the transitory and enduring benefits relative to the costs that are generated due to the interaction of the collaborators and that accrue to organizations, individuals, and society" (Austin \& Seitanidi, 2012, p. 945).

Some scholars have highlighted the lack of comprehensive studies on the societal outcomes of partnerships (Clarke \& Crane, 2018; Pattberg \& Widerberg, 2016; Vestergaard et al., 2020). As Austin and Seitanidi (2012) put it, "there is a tendency to assume societal betterment rather than provide the necessary evidence" (p.957). In their qualitative study of 
an NGO-business partnership in Ghana aiming at poverty alleviation, Vestergaard et al. (2020) found that the partnership resulted in what they call 'competences without agency'. Focusing on the outputs for the beneficiaries, the authors show that the partnership provided basic needs to the beneficiaries however its potential to create a transformational impact failed. The competences which the beneficiaries acquired through the partnership actually were "fenced in the partnership to protect commercial interest of the business partner" (Vestergaard et al., 2020, p. 1372). Beneficiaries had little control over the resources and competences they acquired which limited their ability to use them for their own purpose. The study points to the fact that partnerships tend to take a company's perspective, overlooking the impact and the consequences of partnerships for the beneficiaries and the grand challenges they are supposed to tackle.

Research has also questioned the myth of inclusiveness in partnership (Baur \& Schmitz, 2012; Nelson \& Tallontire, 2014). Indeed, partnerships face the challenge of overcoming unequal power relations among actors (Bitzer \& Glasbergen, 2015). Moreover, partnerships tend to embody a constructive approach to market-based approaches in development, where businesses have been attributed active role in addressing societal challenges (Blowfield \& Dolan, 2014). Those have been criticised for not being able to address the root structural causes of the problems (Arora \& Romijn, 2011; Banks \& Hulme, 2014).

\section{A broken dialogue with missing voices}

The criticisms on partnerships and the lack of understanding of their societal impacts directly question whether 'partnership' is always the most suitable strategy and organizing form to address the SDGs. It outlines the need to critically revisit the very essence of what the partnership form entails and whether a real or authentic dialogue is taking place in partnerships. Roberts (2002) defines authentic dialogue as "a process of mutual understanding that emerges when participants treat each other with equality, not coercion, and when they listen empathically to one another's concerns in order to probe their fundamental assumptions and world views" $(2002,660)$. Dialogue can therefore be understood as a social interaction through which stakeholders build relationships, expand their knowledge and transform their worldviews. Expressed in terms of Bakhtin's notion of 
polyphony (see e.g., Belova et al., 2008), dialogue results from the expression of multiple voices.

Dialogue is an indispensable aspect of collaboration and true partnership (Burchell \& Cook, 2013; Seitanidi \& Crane, 2009; Van Tulder et al., 2016), however partnerships do not always involve dialogue going beyond a one-way communication (monologue) or the traditional conflictual or instrumental process of communication (Brand et al., 2020; Crane \& Livesey, 2003). We argue that acting for sustainability requires dialogue that involves co-creative processes and cooperative efforts to understand the multidimensional challenges.

The importance of aiming for an inclusive dialogue becomes more salient for less powerful civil society actors who might be excluded from those formal forms of dialogue and collaboration that are partnerships. Indeed, partnerships and corporate social responsibility more generally tend to be designed by the partners or stakeholders who are the most important and powerful while marginalized actors are often unheard or silenced (Banerjee, 2011; Jamali \& Sidani, 2011; Lauwo, 2018). Although the inclusion of multiple stakeholders is critical in dialogue (Boström, 2006; Mena \& Palazzo, 2012), inclusiveness is sometimes perceived as conflicting with the principles of efficiency that dominate partnerships (Henry et al., 2020; Hong, 2015). As Henry et al. (2020) put it, "any perception of inefficiency in terms of wasted time and effort may jeopardize participants' willingness and ability to continue participating in a partnership, risking reducing the inclusiveness of the partnership and potentially even undermining its purpose altogether". This directly questions the capacity of partnerships to deliver the kind of dialogue that can lead to societal betterment.

Meanwhile, the multi-stakeholder partnerships promoted by SDG 17 are also characterized by the persistence of conflicts where certain communities are bound to be 'losers' (e.g., of land rights and livelihoods). The risk with multi-stakeholder partnerships is that the voices of these communities become suppressed by the guise of broad representation and consensus. This sheds light on the desirability of various expressions of dissensus and agonistic dialogue (Brown \& Tregidga, 2017; Dillard \& Brown, 2015; Fougère \& Solitander, 2020). Thus, imagining different types of institutional arrangements - moving away from consensusdriven partnerships - that could give a space for a democratic expression of these tensions through dialogue is important.

To us, the literature seems to have missed an essential aspect of partnership: this very concept

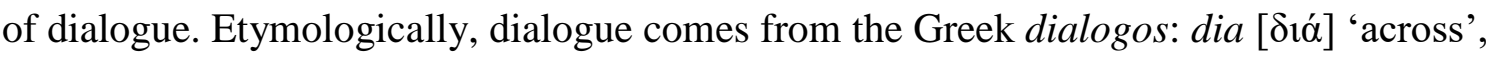




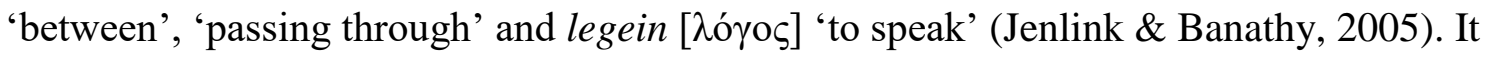
means a speech across, between, through two or more people, and involves a flow of meaning as a collective out of which may emerge new understanding. In a true dialogue, there is no talking without listening and the in-between is more important than the being. As Buber (1965) argued, dialogue is above all relational in the sense that "meaning is to be found neither in one of the two partners nor in both together, but only in their dialogue itself, in the 'between' which they live together". Dialogue is therefore both a conversation in which people think together in relationships and an acknowledgement and integration of the 'other' (Gear et al., 2003). Cheney and Christensen (2001) characterize genuine dialogue as "a dialogue in which questions of interest and representation are constantly negotiated" (p. 260). Genuine dialogue is geared toward mutual education, joint problem solving and relationship building. It can also be described as a high quality form of engagement (Crane \& Livesey, 2003). A partnership without genuine dialogue cannot be transformative, and for this special issue we called for a deeper understanding of the relationship between partnerships and dialogue.

\section{Articles included in this special issue}

Inspired by the above arguments, this special issue aims at providing readers with a theoretical understanding of partnership and cross-sector dialogue among civil society organizations, businesses and their associated supply chains. This understanding may take partnership as a starting point for good dialogue, but may also problematize the partnership imperative implied by SDG 17 and suggest alternative paths for effective dialogue conducive to sustainable development.

Even though we called for such tensions to be the focus of the contribution of this special issue, we have found that most of the submitted papers tended to accept, normatively and unquestionably, the place of cross-sector partnerships in addressing the SDGs and more broadly their use in seeking social responsibility outcomes. While we would have wished for more explicit problematization of the potential pitfalls of a partnership imperative by which the only path to sustainability is partnership, the articles of this special issue provide insightful contributions to the literature on partnerships. They illuminate various forms of partnerships that are being used in international contexts, across different industries and 
within and across sectors. They also demonstrate the variety of factors or contingencies that lead to their formation, enable their development and produce outcomes across micro-, mesoand macro- levels.

Fontana et al. (2021) study a case involving multiple organizations operating locally in the apparel industry of Bangladesh, looking into how the cross-sector collaboration process can help improve the conditions of female workers. They examine the influence of what they call 'nonprofit boundary work' during that process. Their analysis suggests that such nonprofit boundary work consists of (1) scaffolding work (where development agency workers set up boundaries) and (2) sensitization work (where NGO workers blur and expand these boundaries). This boundary work particularly leverages the social capital of 'sustainability envoys' to support the female workers in the factories and in their communities.

Kumar et al. (2021) investigate a range of Australian public and private sector co-opetitive strategies, used to bring together competing firms as collaborators, to improve performance across economic, social and environmental sustainability. In acknowledging the risk and tensions inherent in competitive relationships, the study investigates similar and different motives and drivers of co-opetitive strategies, as well as outcomes from the co-opetitive initiatives. It moves the discussion from the oft-used dichotomous approach to co-opetition, as being either competitive or collaborative, to present a typology that depicts the interplay between the two concepts. It concludes that competition-dominated co-opetition may lead to improved economic performance whilst cooperation-dominated co-opetition leads to improved social-environmental performance. To bring about improvements across all three dimensions of economic, social and environmental performance, the authors argue that there is a need for a balanced-strong coopetition approach with a focus on both value creation and value appropriation. The paper also brings to the fore key success factors for co-opetitive relationships in CSR and sustainability, namely CSR and sustainability governance, CSR and sustainability public-policy, and relationship principles. In highlighting further research the paper points to the need to add national context to include cultural and legal contextual factors.

Ordonez-Ponce et al. (2021) examine how four large local partnerships enable businesses to contribute to the achievement of the SDGs, with specific focus on Local Agenda 21 plans in partnership with other organizations situated in their city. They investigate why firms partner and what outcomes they obtain from partnering, notably from a resource-based view 
perspective. Their findings suggest that from the latter perspective, these local sustainability partnerships are valuable for the businesses, and that their framings in terms of SDG targets are overall well aligned with the reasons why the firms join the partnerships. Their study shows that firms of all sizes can enhance both local and global sustainability objectives by engaging in such local partnerships.

Ryan and Hauser (2021) explore partnerships among business schools, a type of institution that had not yet been considered by the partnerships literature. The Principles of Responsible Management Education (PRME), with more than 850 signatories, strongly encourages universities and business school partnerships and dialogue (principle 5 and 6). Building from the partnerships literature, the authors build a three-dimensional framework of partnerships and use it to analyze the partnership activities of 13 leading PRME business schools. The findings show a great variety of partnership activities ranging from informal one-off events to more long-standing projects revealing the plasticity of the term partnership. The study highlights the pluriform nature of partnerships. The authors suggest taking a portfolio lens to analyze partnership activities to 'allow business schools to reflect on the partnership activity holistically while reflecting on the balance between the beneficiaries of these activities' (p. to be added by the publisher). The framework offered in this paper can help business schools and other organizations to map the various partnership activities they are involved in and work towards a "blend of partnerships" to create wider societal benefits.

Yin (2021) studies Chinese social partnerships between MNCs and non-profits in terms of value creation for sustainability. Being focused on cross-sector social partnerships, it adopts a collaborative approach to bring about economic, social and environmental performance. Specifically, the authors highlight the challenges for MNCs operating in China with institutional voids, difficulties in bridging formal and informal institutions, and lack of knowledge of local markets; thus pointing to the importance of forming relationships with local non-profit organisations. Adopting a comparative case study method, the paper investigates 12 social partnerships addressing sustainability in China. Drawing on Austin's (2000) and Austin and Seitanidi's (2012a) collaboration continuum model as an analytical tool, it aims to highlight the characteristics, factors, and contingencies that enable or impede the value creation potential of social partnerships in China. In adopting a resource based approach, for both partners, collaboration is discussed as a means to gain complementary social resources and improve stakeholder relationships, provide organisational legitimacy, 
reputation, social capital, networks and organisational learning; as well as better ethical and responsible practices. The difficulties however are also acknowledged in terms of different backgrounds and experiences of the partners. The importance of multi-directional resource and information exchange is highlighted in order to optimise the potential of each partner's social expertise. The paper concludes that collaborative value has been found to mainly occur at the micro or meso levels whereas transformational outcomes achieved over the long term are minimal. Many partnerships studied were philanthropic and transactional, oriented towards 'satisficing' rather than 'optimising', with a few classified as integrative or transformational. To bring about the latter, the authors highlight the need for high resource complementarity, centrality to mission, trust building, multi-faceted accountability, learning and knowledge sharing, high synergist value and innovation, and a focus on external system change.

Carr et al. (2021) focus their attention on social enterprises in Vietnam. They explore whether and to what extent differences in the social impacts of those enterprises may be explained by the psychological characteristics of the entrepreneurs and the cross-sector ecosystem partnerships in training, networking, consultation and funding. The notion of ecosystem enables the authors to take a wider perspective on partnership and consider complex dynamics between the social enterprise and its stakeholders. The study shows that ecosystem partnership had both direct and moderating links to social impacts of social enterprises in Vietnam, highlighting the importance of those relationships.

\section{Key learnings}

We would like to highlight five main key learnings that emerged from the different articles from this special issue:

1. High level of hybridity of the partnership form;

2. Importance of context;

3. Importance of individuals and their social networks;

4. Tendency to analyse the partnership form through resource theories; and

5. Reluctance to adopt a critical lens 
A first key takeaway from the special issue as a whole relates to the high level of 'hybridity' of collaboration forms that are labelled as 'partnership' (Ryan \& Hauser, 2021). In several of the articles and in line with previous studies (Henry et al., 2020; Sharma \& Bansal, 2017; Stadtler, 2018), it is alluded that these hybrid forms of collaboration involve important tensions. Kumar et al. (2021) note that co-opetition implies competitive tensions, which need to be managed. Ryan and Hauser (2021) reflect on the plasticity of the notion of partnership in the university context, and observe that this makes it possible to add the label of 'partnerships' in different forms of cooperation, some of which may not be very well aligned or very friendly. In the completely different context of cross-sector partnerships in China, Yin (2021) suggests that the goal for individuals of building their guanxi networks might not be fully aligned with the explicitly stated goals of the partnerships.

A second important learning concerns the context specificity of insights about partnerships. In order to understand collaboration patterns, the contributions of this special issue highlight how important it is to learn more about the specific roles of community leaders in Bangladesh (Fontana et al., 2021), but also the translations of Local Agenda 21 (LA21) in different local contexts (Ordonez-Ponce et al., 2021), the particular Chinese conditions whereby social partnerships serve as an indirect way to navigate stakeholder relationships (Yin, 2021), and the idiosyncrasies of Vietnamese social enterprises (Carr et al., 2021). In other words, those studies point to the need to understand partnerships in the context in which they occur as Vurro and Dacin (2014) have also highlighted and therefore to study their embeddedness.

A third theme that runs through several of the articles emphasizes the importance of the individuals and their personal social networks in cross-sector collaboration. Indeed, individuals and their networks tend to have a decisive influence on various aspects that might determine the success of partnerships. Fontana et al. (2021) underline the role of 'sustainability envoys' involved in boundary work, and from whom much of the value of the partnerships is made possible. Ryan and Hauser (2021) make a distinction between university partnerships whose commitment is largely institution-based and those that are largely based on individual commitments, pointing to the fact that the latter are often those with higher motivation and more meaningful impact from the perspective of the individuals involved. Yin (2021) also lifts up the importance of individual guanxi networks in patterns of collaboration in China.

Fourth, there are also takeaways that we believe can be drawn from what is generally assumed to be the established way to write about partnerships, which might lead to forms of 
myopia. We highlight two trends that we find striking in this regard and that point to avenues for further research. There is a trend to tie the discussion of partnerships to questions of resources and resource complementarity, sometimes in explicit reference to the 'resourcebased view' of strategy. This trend is particularly visible in relation to co-opetition (Kumar et al., 2021), the LA21-related partnerships (Ordonez-Ponce et al., 2021), and the central issue of resource complementarity in the Chinese partnerships (Yin, 2021). We would suggest that especially in relation to partnerships that aim for sustainability outcomes, it would be important to go beyond the resource-based view, and beyond cost-benefit analyses, and instead to think of the value derived from partnerships as something that would be more decentred from the partners, and clearly aimed FOR sustainability.

The last trend which we find striking in the articles relates to the reluctance to be explicitly critical when discussing partnerships, and perhaps the acceptance that partnerships have to be seen in a good light, as a part of the solution, because SDG 17 says so, as it were. This is by no means a new observation - within business and society research at least, the narrative that NGOs have decided to move from adversarial relations to partnerships as an implicitly more valuable form of engagement was established long ago and has since then been reproduced (see Laasonen et al., 2012). What is problematic in this belief in the virtue of cross-sector partnerships is the potential myopia it entails - and the possible consequent inability to select modes of engagement that might be more effective than partnerships in relation to particular sustainability goals. Thus, in our suggestions for further research below, we suggest some avenues that may go beyond the partnership imperative.

\section{Further research: three key tensions to be explored}

Based on both previous literature and the articles included in this special issue, we conclude that the tensions between 'partnerships' and 'dialogue' need to be given more attention by business and society scholars. Many scholars have questioned the quality of dialogue in partnerships and normatively promoted more relational practices in partnerships (Lambrechts et al., 2009), positive institutional collaborations (Nilsson, 2015), and rebalancing the relation among societies, businesses, and their associated supply chains, and governments (Azevedo \& Gates, 2019; Mintzberg, 2015). We need more empirical examples where dialogue and relational practices are put in place as we believe those are indispensable for the learning to take place and to reach transformational change. 
In addition, in business and society literature and more generally in discussions that engage with SDG 17, there is a strong, dominant tendency to treat partnerships unproblematically as the desirable approach to address sustainability challenges. Comparatively, there still are only few studies that look into other forms of dialogue than partnership, particularly in the space between 'adversarial' and 'partnership' (Burchell \& Cook, 2013; Laasonen et al., 2012). In our view, it is important to call for more studies that engage with the nuances and intricacies of empirical forms of dialogue that do not fall neatly in the category 'partnership'. These types of dialogue, often based on organizations that take watchdog roles, resist the language of partnerships as they feel they cannot make a difference if from the outset their engagement with corporations is framed in only collaborative ways, without acknowledging the inherent tensions. One reason why business and society literature does not emphasize these approaches more lies in an imbalance, in that literature, between on the one hand, an emphasis on business strategies and, on the other hand, a comparative lack of consideration for the strategic interests and pragmatic approaches of NGOs or CSOs. In these times of partnership imperative, because of both the SDGs and changes in development aid policies incentivizing partnerships across the board (Bull \& Miklian, 2019; Menashy \& Shields, 2017; Rozbicka \& Szent-Iványi, 2020), the number of dialogue-oriented organizations deliberately rejecting the partnership form is intriguing and suggests that partnerships as such might suppress true dialogue. This warrants more empirical studies focused on these types of organizations.

Recently, many studies have been published on 'agonistic dialogue' and the question of 'dissent' in business and society (e.g. Barthold \& Bloom, 2020; Brand et al., 2020; Couch \& Bernacchio, 2020; Dawkins, 2019; Fougère \& Solitander, 2020; Rhodes et al., 2020; Sorsa \& Fougère, 2020). They suggest that there is resistance to the 'one way fits all' SDG 17 narrative. Empirical studies focused on dissent and resistance within partnerships and other cross-sector collaborative efforts would make business and society research better attuned to the political and social complexity of cross-sector interactions that happen under the frictionless sounding term 'partnership'.

\section{References}


Albers, S., Wohlgezogen, F., \& Zajac, E. J. (2013). Strategic Alliance Structures: An Organization Design Perspective. Journal of Management, 42(3), 582-614. https://doi.org/10.1177/0149206313488209

Arora, S., \& Romijn, H. (2011). The empty rhetoric of poverty reduction at the base of the pyramid. Organization, 19(4), 481-505. https://doi.org/10.1177/1350508411414294

Austin, J. E. (2000). Strategic Collaboration Between Nonprofits and Businesses. Nonprofit and Voluntary Sector Quarterly, 29(1_suppl), 69-97. https://doi.org/10.1177/0899764000291S004

Austin, J. E., \& Seitanidi, M. M. (2012). Collaborative Value Creation:A Review of Partnering Between Nonprofits and Businesses: Part I. Value Creation Spectrum and Collaboration Stages. Nonprofit and Voluntary Sector Quarterly, 41(5), 726-758. https://doi.org/10.1177/0899764012450777

Azevedo, G., \& Gates, A. (2019). Wake Up! The World Is Out of Balance and If You Do Nothing You Are Part of the Problem: An Interview With Henry Mintzberg. Journal of Management Inquiry, 28(2), 180-186. https://doi.org/10.1177/1056492618761811

Banerjee, S. B. (2011). Voices of the Governed: towards a theory of the translocal. Organization, 18(3), 323-344. https://doi.org/10.1177/1350508411398729

Banks, N., \& Hulme, D. (2014). New development alternatives or business as usual with a new face? The transformative potential of new actors and alliances in development. Third World Quarterly, 35(1), 181-195. https://doi.org/10.1080/01436597.2014.868997

Barthold, C., \& Bloom, P. (2020). Denaturalizing the Environment: Dissensus and the Possibility of Radically Democratizing Discourses of Environmental Sustainability. Journal of Business Ethics, 164(4), 671-681. https://doi.org/10.1007/s10551-019-04397-0

Baur, D., \& Schmitz, H. P. (2012). Corporations and NGOs: When Accountability Leads to Co-optation. Journal of Business Ethics, 106(1), 9-21. https://doi.org/10.1007/s10551-011-1057-9

Belova, O., King, I., \& Sliwa, M. (2008). Introduction: Polyphony and Organization Studies: Mikhail Bakhtin and Beyond. Organization Studies, 29(4), 493-500. https://doi.org/10.1177/0170840608088696

Bitzer, V., \& Glasbergen, P. (2015). Business-NGO partnerships in global value chains: part of the solution or part of the problem of sustainable change? Current Opinion in Environmental Sustainability, 12, 35-40. https://doi.org/https://doi.org/10.1016/j.cosust.2014.08.012

Blowfield, M., \& Dolan, C. S. (2014). Business as a development agent: evidence of possibility and improbability. Third World Quarterly, 35(1), 22-42.

https://doi.org/10.1080/01436597.2013.868982 
Boström, M. (2006). Regulatory Credibility and Authority through Inclusiveness: Standardization Organizations in Cases of Eco-Labelling. Organization, 13(3), 345-367. https://doi.org/10.1177/1350508406063483

Brand, T., Blok, V., \& Verweij, M. (2020). Stakeholder Dialogue as Agonistic Deliberation: Exploring the Role of Conflict and Self-Interest in Business-NGO Interaction [Article]. Business Ethics Quarterly, 30(1), 3-30. https://doi.org/10.1017/beq.2019.21

Brown, J., \& Tregidga, H. (2017). Re-politicizing social and environmental accounting through Rancière: On the value of dissensus. Accounting, Organizations and Society, 61, 1-21. https://doi.org/10.1016/i.aos.2017.08.002

Bryson, J. M., Crosby, B. C., \& Stone, M. M. (2006). The Design and Implementation of Cross-Sector Collaborations: Propositions from the Literature. Public Administration Review, 66(s1), 4455. https://doi.org/https://doi.org/10.1111/j.1540-6210.2006.00665.x

Buber, M. (1965). The Knowledge of Man. Allen and Unwin.

Bull, B., \& Miklian, J. (2019). Towards global business engagement with development goals? Multilateral institutions and the SDGs in a changing global capitalism. Business and Politics, 21(4), 445-463. https://doi.org/10.1017/bap.2019.27

Burchell, J., \& Cook, J. (2013). CSR, Co-optation and Resistance: The Emergence of New Agonistic Relations Between Business and Civil Society. Journal of Business Ethics, 115(4), 741-754. https://doi.org/10.1007/s10551-013-1830-z

Carr, S., Nguyen, M. H., Hodgetts, D., \& Fauchart, E. (2021). Why do some Social Enterprises flourish in Vietnam? A Comparison of Human and Ecosystem Partnerships. Sustainability Accounting, Management and Policy Journal, 13.

Cheney, G., \& Christensen, L. (2001). Organizational communication: Linkages between internal and external communication. In The New Handbook of Organizational Communication (pp. 231269). SAGE Publications, Inc. https://doi.org/10.4135/9781412986243

Cheyns, E. (2014). Making "minority voices" heard in transnational roundtables: the role of local NGOs in reintroducing justice and attachments. Agriculture and Human Values, 31(3), 439453. https://doi.org/10.1007/s10460-014-9505-7

Clarke, A., \& Crane, A. (2018). Cross-Sector Partnerships for Systemic Change: Systematized Literature Review and Agenda for Further Research. Journal of Business Ethics, 150(2), 303313. https://doi.org/10.1007/s10551-018-3922-2

Clarke, A., \& Fuller, M. (2010). Collaborative Strategic Management: Strategy Formulation and Implementation by Multi-Organizational Cross-Sector Social Partnerships. Journal of Business Ethics, 94(1), 85-101. https://doi.org/10.1007/s10551-011-0781-5 
Clarke, A., \& Macdonald, A. (2019). Outcomes to Partners in Multi-Stakeholder Cross-Sector Partnerships: A Resource-Based View. Business \& Society, 58(2), 298-332. https://doi.org/10.1177/0007650316660534

Clarke, A., \& Ordonez-Ponce, E. (2017). City scale: Cross-sector Partnerships for Implementing Local Climate Mitigation Plans. Speak your Mind Symposium on Climate Change and Public Administration. Public Administration Review,

Couch, R., \& Bernacchio, C. (2020). The Virtues of Equality and Dissensus: Maclntyre in a Dialogue with Rancière and Mouffe. Journal of Business Ethics, 164(4), 633-642. https://doi.org/10.1007/s10551-019-04400-8

Crane, A., \& Livesey, S. M. (2003). Are You Talking to Me? Stakeholder Communication and the Risks and Rewards of Dialogue. In J. Andriof, S. Waddock, B. Husted, \& S. Sutherland Rahman (Eds.), Unfolding Stakeholder Thinking 2: Relationships, Communication, Reporting and Performance (pp. 39-52). Greenleaf. Available at SSRN: https://ssrn.com/abstract=2367527

Crane, A., \& Seitanidi, M. (2014). Social partnerships and responsible business: What, why, and how? . In M. Seitanidi \& A. Crane (Eds.), Social Partnerships and Responsible Business: A Research Handbook (pp. 1-12). Routledge.

Dawkins, C. E. (2019). An Agonistic Notion of Political CSR: Melding Activism and Deliberation. Journal of Business Ethics. https://doi.org/10.1007/s10551-019-04352-z

Dillard, J., \& Brown, J. (2015). Broadening out and opening up: an agonistic attitude toward progressive social accounting. Sustainability Accounting, Management and Policy Journal, 6(2), 243-266. https://doi.org/10.1108/sampj-09-2014-0055

Fadeeva, Z. (2005). Promise of sustainability collaboration-potential fulfilled? Journal of Cleaner Production, 13(2), 165-174. https://doi.org/https://doi.org/10.1016/S0959-6526(03)00125-2

Fontana, E., Heuer, M., \& Koep, L. (2021). Cross-sector collaboration and nonprofit boundary work for female workers in developing countries: Evidence from Bangladesh. Sustainability Accounting, Management and Policy Journal, 13.

Fougère, M., \& Solitander, N. (2020). Dissent in Consensusland: An Agonistic Problematization of Multi-stakeholder Governance. Journal of Business Ethics, 164(4), 683-699. https://doi.org/10.1007/s10551-019-04398-z

Gear, T., Vince, R., Read, M., \& Leonard Minkes, A. (2003). Group enquiry for collective learning in organisations. Journal of Management Development, 22(2), 88-102. https://doi.org/doi:10.1108/02621710310459676

Glasbergen, P. (2011). Understanding partnerships for sustainable development analytically: the ladder of partnership activity as a methodological tool. Environmental Policy and Governance, 21(1), 1-13. 
Gray, B., \& Stites, J. P. (2013). Sustainability through partnerships: Capitalizing on collaboration. nbs.net/knowledge

Gupta, A., Mattison, J., Mitchell, R., \& Trescott, J. (2018). Transforming Partnerships for the SDGs. https://www.unglobalcompact.org/library/5614

Head, B. W. (2008). Wicked problems in public policy. Public Policy, 3(2), 101-108.

Henry, L. A., Rasche, A., \& Möllering, G. (2020). Managing Competing Demands: Coping With the Inclusiveness-Efficiency Paradox in Cross-Sector Partnerships. Business \& Society, Forthcoming(1-38). https://doi.org/10.1177/0007650320978157

Hong, S. (2015). Citizen Participation in Budgeting: A Trade-Off between Knowledge and Inclusiveness? Public Administration Review, 75(4), 572-582.

https://doi.org/https://doi.org/10.1111/puar.12377

Horan, D. (2019). A New Approach to Partnerships for SDG Transformations. Sustainability, 11(18), 4947. https://doi.org/10.3390/su11184947

Huxham, C., \& Vangen, S. (2005). Managing to Collaborate. Routlege.

Jamali, D., \& Sidani, Y. (2011). Is CSR Counterproductive In Developing Countries: The Unheard Voices of Change. Journal of Change Management, 11(1), 69-71. https://doi.org/10.1080/14697017.2011.548940

Jenlink, P. M., \& Banathy, B. (2005). Dialogue: Conversation as Culture Building and Consciousness Evolving. In B. Banathy \& P. M. Jenlink (Eds.), Dialogue as a Means of Collective Communication (pp. 3-16). Springer.

Kolk, A. (2014). Partnerships as panacea for addressing global problems? . In M. Seitanidi \& A. Crane (Eds.), Social Partnerships and Responsible Business: A Research Handbook. Routledge.

Kumar, A., Bhattacharyya, A., \& Connell, J. (2021). Co-opetition for Corporate Social Responsibility and Sustainability: drivers and success factors. Sustainability Accounting, Management and Policy Journal, 13.

Laasonen, S., Fougère, M., \& Kourula, A. (2012). Dominant Articulations in Academic Business and Society Discourse on NGO-Business Relations: A Critical Assessment. Journal of Business Ethics, 109(4), 521-545. https://doi.org/10.1007/s10551-011-1143-z

Lambrechts, F., Grieten, S., Bouwen, R., \& Corthouts, F. (2009). Process Consultation Revisited. The Journal of Applied Behavioral Science, 45(1), 39-58.

https://doi.org/10.1177/0021886308326563 
Lauwo, S. (2018). Challenging Masculinity in CSR Disclosures: Silencing of Women's Voices in Tanzania's Mining Industry. Journal of Business Ethics, 149(3), 689-706.

https://doi.org/10.1007/s10551-016-3047-4

Lotia, N., \& Hardy, C. (2008). Critical Perspectives on Collaboration. In S. Cropper, C. Huxham, M. Ebers, \& P. S. Ring (Eds.), The Oxford Handbook of Inter-Organizational Relations (pp. 366389). Oxford University Press.

MacDonald, A., Clarke, A., \& Huang, L. (2019). Multi-stakeholder Partnerships for Sustainability: Designing Decision-Making Processes for Partnership Capacity. Journal of Business Ethics, 160(2), 409-426. https://doi.org/10.1007/s10551-018-3885-3

McDonald, S., \& Young, S. (2012). Cross-sector collaboration shaping Corporate Social Responsibility best practice within the mining industry. Journal of Cleaner Production, 37, 54-67. https://doi.org/https://doi.org/10.1016/j.jclepro.2012.06.007

Mena, S., \& Palazzo, G. (2012). Input and Output Legitimacy of Multi-Stakeholder Initiatives. Business Ethics Quarterly, 22(3), 527-556. https://doi.org/10.5840/beq201222333

Menashy, F., \& Shields, R. (2017). Unequal partners? Networks, centrality, and aid to international education. Comparative Education, 53(4), 495-517. https://doi.org/10.1080/03050068.2017.1323822

Mintzberg, H. (2015). Rebalancing society: Radical renewal beyond left, right, and center. BerrettKoehler.

Murray, A., Haynes, K., \& Hudson, L. J. (2010). Collaborating to achieve corporate social responsibility and sustainability? Sustainability Accounting, Management and Policy Journal, 1(2), 161-177. https://doi.org/10.1108/20408021011089220

Nelson, V., \& Tallontire, A. (2014). Battlefields of ideas: changing narratives and power dynamics in private standards in global agricultural value chains. Agriculture and Human Values, 31(3), 481-497. https://doi.org/10.1007/s10460-014-9512-8

Nilsson, W. (2015). Positive Institutional Work: Exploring Institutional Work Through the Lens of Positive Organizational Scholarship. Academy of management Review, 40(3), 370-398. https://doi.org/10.5465/amr.2013.0188

Ordonez-Ponce, E., \& Clarke, A. (2020). Sustainability cross-sector partnerships: The strategic role of organizational structures. Corporate Social Responsibility and Environmental Management, 27(5), 2122-2134. https://doi.org/https://doi.org/10.1002/csr.1952

Ordonez-Ponce, E., Clarke, A., \& MacDonald, A. (2021). Business Contributions to the Sustainable Development Goals through Community Sustainability Partnerships. Sustainability Accounting, Management and Policy Journal, 13. 
Pattberg, P., \& Widerberg, O. (2016). Transnational multistakeholder partnerships for sustainable development: Conditions for success. Ambio, 45(1), 42-51. https://doi.org/10.1007/s13280$\underline{015-0684-2}$

Pedersen, E. R. G., Lüdeke-Freund, F., Henriques, I., \& Seitanidi, M. M. (2020). Toward Collaborative Cross-Sector Business Models for Sustainability. Business \& Society. https://doi.org/10.1177/0007650320959027

Rhodes, C., Munro, I., Thanem, T., \& Pullen, A. (2020). Dissensus! Radical Democracy and Business Ethics. Journal of Business Ethics, 164(4), 627-632. https://doi.org/10.1007/s10551-019$\underline{04405-3}$

Roberts, N. C. (2002). Keeping Public Officials Accountable through Dialogue: Resolving the Accountability Paradox. Public Administration Review, 62(6), 658-669. https://doi.org/https://doi.org/10.1111/1540-6210.00248

Rondinelli, D. A., \& London, T. (2003). How corporations and environmental groups cooperate: Assessing cross-sector alliances and collaborations. Academy of Management Perspectives, 17(1), 61-76. https://doi.org/10.5465/ame.2003.9474812

Rozbicka, P., \& Szent-Iványi, B. (2020). European development NGOs and the diversion of aid: Contestation, fence-sitting, or adaptation? Development Policy Review, 38(2), 161-179. https://doi.org/https://doi.org/10.1111/dpr.12417

Rundall, P. (2000). The perils of partnership-An NGO perspective. Addiction 95, 1501-1504.

Ryan, A., \& Hauser, C. (2021). Higher education institutions, PRME, and partnerships for the goals: Retrofit labeling or driving force for change? Sustainability Accounting, Management and Policy Journal, 13.

Sachs, J. D., Schmidt-Traub, G., Mazzucato, M., Messner, D., Nakicenovic, N., \& Rockström, J. (2019). Six Transformations to achieve the Sustainable Development Goals. Nature Sustainability, 2(9), 805-814. https://doi.org/10.1038/s41893-019-0352-9

Schouten, G., Leroy, P., \& Glasbergen, P. (2012). On the deliberative capacity of private multistakeholder governance: The Roundtables on Responsible Soy and Sustainable Palm Oil. Ecological Economics, 83, 42-50. https://doi.org/https://doi.org/10.1016/j.ecolecon.2012.08.007

Seitanidi, M., \& Crane, A. (2009). Implementing CSR Through Partnerships: Understanding the Selection, Design and Institutionalisation of Nonprofit-Business Partnerships. Journal of Business Ethics, 85(2), 413-429.

Seitanidi, M., \& Crane, A. (2014). Social partnerships and responsible business: A Research Handbook. Routledge. 
Seitanidi, M. M., Koufopoulos, D. N., \& Palmer, P. (2010). Partnership Formation for Change: Indicators for Transformative Potential in Cross Sector Social Partnerships. Journal of Business Ethics, 94(1), 139-161. https://doi.org/10.1007/s10551-011-0784-2

Selsky, J. W., \& Parker, B. (2005). Cross-Sector Partnerships to Address Social Issues: Challenges to Theory and Practice. Journal of Management, 31(6), 849-873. https://doi.org/10.1177/0149206305279601

Sharma, G., \& Bansal, P. (2017). Partners for Good: How Business and NGOs Engage the Commercial-Social Paradox. Organization Studies, 38(3-4), 341-364. https://doi.org/10.1177/0170840616683739

Sorsa, V.-P., \& Fougère, M. (2020). Toward Political Explanation of Change in Corporate Responsibility: Political Scholarship on CSR and the Case of Palm Oil Biofuels. Business \& Society. https://doi.org/10.1177/0007650320915919

Stadtler, L. (2018). Tightrope Walking: Navigating Competition in Multi-Company Cross-Sector Social Partnerships. Journal of Business Ethics, 148(2), 329-345. https://doi.org/10.1007/s10551$\underline{\text { 017-3579-2 }}$

Tulder, R., Seitanidi, M., Crane, A., \& Brammer, S. (2016). Enhancing the Impact of Cross-Sector Partnerships [Article]. Journal of Business Ethics, 135(1), 1-17. https://doi.org/10.1007/s10551-015-2756-4

UN. (2019). Transforming Our World: The 2030 Agenda for Sustainable Development. https://sustainabledevelopment.un.org/post2015/transformingourworld

Van Huijstee, M. M., Francken, M., \& Leroy, P. (2007). Partnerships for sustainable development: a review of current literature. Environmental Sciences, 4(2), 75-89. https://doi.org/10.1080/15693430701526336

Van Tulder, R., Seitanidi, M. M., Crane, A., \& Brammer, S. (2016). Enhancing the Impact of CrossSector Partnerships. Journal of Business Ethics, 135(1), 1-17. https://doi.org/10.1007/s10551-015-2756-4

Vestergaard, A., Murphy, L., Morsing, M., \& Langevang, T. (2020). Cross-Sector Partnerships as Capitalism's New Development Agents: Reconceiving Impact as Empowerment. Business \& Society, 59(7), 1339-1376. https://doi.org/10.1177/0007650319845327

Vurro, C., \& Dacin, T. M. (2014). An institutional perspective on cross-sector partnership. In M. M. Seitanidi \& A. Crane (Eds.), Social Partnerships and Responsible Business: A Research Handbook. Routledge.

Waddock, S. (1989). Understanding Social Partnerships. An Evolutionary Model of Partnership Organisations. Administration \& Society, 21(1), 78-100. 
Waddock, S. A. (1991). A Typology of Social Partnership Organizations. Administration \& Society, 22(4), 480-515. https://doi.org/10.1177/009539979102200405

Whittington, C. (2003). Collaboration and Partnership in Context. In J. Weinstein, C. Whittington, \& T. Leiba (Eds.), Collaboration in Social Work Practice (pp. 13-38). Jessica Kingsley Publishers.

Yin, J. (2021). How multinational corporations and nonprofits collaborate for sustainability: assessing social partnerships from China. Sustainability Accounting, Management and Policy Journal, 13. 